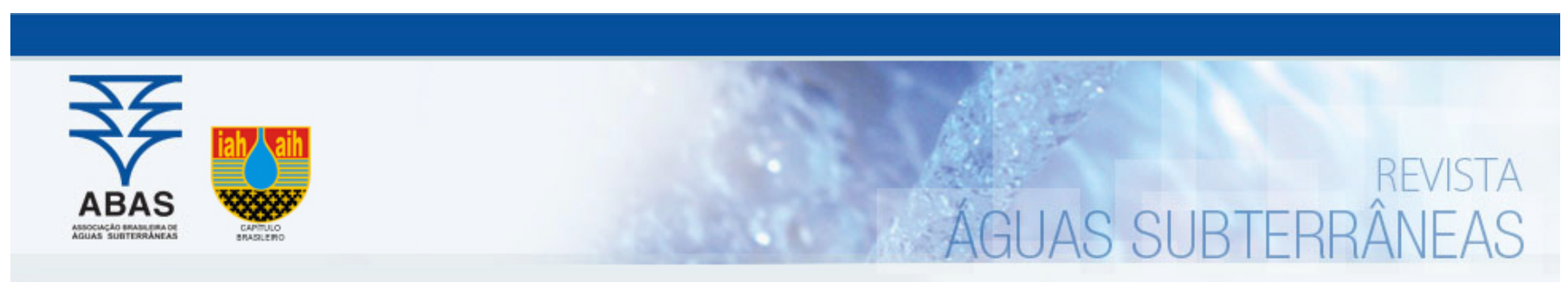

Artigos

\title{
Groundwater recharge estimating in the Serra Geral aquifer system outcrop area - Paraná State, Brazil
}

\section{Estimativa de recarga das águas subterrâneas no sistema aquífero Serra Geral no Estado do Paraná, Brasil}

\author{
Vinícius Menezes Borges ${ }^{1}$; Fernando Mainardi Fan ${ }^{1}$; Pedro Antônio Roehe Reginato ${ }^{1}$ Gustavo Barbosa Athayde ${ }^{1} \bowtie$ \\ 1 Universidade Federal do Rio Grande do Sul (UFRGS), Porto Alegre, RS, Brasil. \\ $\bowtie$ viniciusborges@ymail.com; fernando.fan@ufrgs.br; pedro.reginato@ufrgs.br; gustavo.athayde@ufrgs.br;
}

\begin{tabular}{ll}
\hline & Abstract \\
\cline { 2 - 2 } $\begin{array}{l}\text { Keywords: } \\
\text { Groundwater recharge. }\end{array}$ & This paper presents a study of groundwater recharge in Serra Geral Aquifer System (SASG) in Paraná. The estimation was per- \\
Baseflow separation. & formed by baseflow separation using the Eckhardt Filter. Three different methods were used for calculating BFImax parameter: \\
Eckhardt Filter. & Inverse Filter, Q90/Q50 Ratio and Eckhardt pondered pre-defined values. The BFImax values were obtained and compared in \\
& each watershed that covers SASG in Paraná. The recharge values obtained ranged from $156,89 \mathrm{~mm} /$ year to $489,18 \mathrm{~mm} /$ year. \\
& The average values calculated by using Inverse Filter, Q90/Q 50 Ratio and Eckhardt Pondered was $355,59 \mathrm{~mm} /$ year, 352,08 \\
& mm/year and $293,81 \mathrm{~mm} /$ year, respectively. The results of the calculated BFImax suggests that pre-defined values for fractured \\
& aquifers by Eckhardt underestimate the recharge in volcanic-rock aquifers, due to its flow conditions. The recharge values ob- \\
& tained showed correlation with area slope and soil type, but not with the predominant aquifer type (sedimentary or fractured). \\
& The highest rates were identified in lower declivity areas and latosol occurrence areas. The obtained recharge values can con- \\
& tribute for a better management of groundwater in Paraná state, however, new studies using new methods are necessary for \\
& validating the results.
\end{tabular}

Resumo

Palavras-chave:

Recarga.

Separação do escoamento de base.

Filtro de Eckhardt.

\section{Revisado por pares.}

Recebido em: 23/05/2017

Aprovado em: $21 / 09 / 2017$

\begin{abstract}
Este trabalho apresenta um estudo da recarga no Sistema Aquífero Serra Geral (SASG) no Paraná. A estimativa foi realizada através da separação do escoamento de base utilizando o Filtro de Eckhardt. Três métodos diferentes foram utilizados para calcular o parâmetro BFImax: Filtro Inverso, Razão Q90/Q50 e ponderação dos valores pré-definidos por Eckhardt, cujos valores obtidos e comparados para cada bacia que abrange o SASG no Paraná. Os valores de recarga obtidos variaram de 156,89 $\mathrm{mm} / \mathrm{ano}$ a $489 \mathrm{~mm} / \mathrm{ano}$, com médias calculadas por Filtro Inverso, Razão Q90/Q50 e Eckhardt Ponderado foram de 355,59 $\mathrm{mm} / \mathrm{ano}, 352,08 \mathrm{~mm} / \mathrm{ano}$ e $293,81 \mathrm{~mm} /$ ano, respectivamente. Os resultados de BFImax sugerem que os valores pré-definidos por Eckhardt para aquíferos fraturados subestimam a recarga em aquíferos vulcânicos. Os valores das taxas de recarga obtidos apresentaram correlação com valores de declividade e tipo de solo na bacia, entretanto, não apresentaram relação com o tipo aquífero (sedimentar ou fraturado). As taxas mais altas foram identificadas em regiões de menor declividade e com ocorrência de latossolo. Estes resultados podem contribuir para uma gestão adequada das águas subterrâneas no Paraná, entretanto, novos estudos são necessários para a validação.
\end{abstract}

DOI: http://dx.doi.org/10.14295/ras.v31i4.28872

\section{INTRODUCTION}

Knowing the groundwater availability is necessary to ensure its sustainability. Groundwater recharge estimation is an important tool for determining the renewable reserves, contributing to the management in quantitative terms. Exploitation rates that exceed recharge may cause aquifer unsustainability. In addition to the quantitative aspects of groundwater, recharge studies also contribute on aquifer vulnerability evaluations. Methods such as DRASTIC (ALLER et al., 1987), SINTACS (CIVITA et al., 1997) and IS (FRANCÉS et al., 2001) uses recharge as an input parameter for aquifer vulnerability evaluation, since aquifers in regions with higher recharge rates are, in general, more vulnerable to contamination, as it facilitates contaminant migration into the saturated zone.
Many methods are commonly used to quantify groundwater re charge (SIMMERS, 1988; HEALY AND COOK, 2002; SCANLON et al., 2002; ECKHARDT, 2005), for example: water balance, water table fluctuation, Darcy law, hydrogeologic models, chemical tracers and baseflow separation. According to Scanlon et al. (2002), groundwater recharge estimation methods has variable reliability.

Baseflow is the flow component in a river which the reaction to rainfall occurs slowly and is usually associated to groundwater discharge (ECKHARDT, 2008). Its determination is essential for the comprehension of water budget and the relation between groundwater and surface water in a watershed (STEWART et al., 2007). By knowing the baseflow, it is possible to estimate groundwater recharge (LEE AND RISLEY, 2002). Baseflow sepa- 
ration consists in the separation of an observed hydrograph of a river in at least two components: surface flow and baseflow. There are many methods to perform a hydrograph separation, including the use of hydrochemical and isotopic tracers and the hydrograph analysis by graphical methods or digital stream-flow filtering (COLLISCHONN AND FAN, 2013).

One famous method is the Eckhardt baseflow filter (ECKHARDT, 2005), which is based in the numerical filtering of a streamflow time-series. Eckhardt's method for baseflow separation consists of a recursive digital filter, based on two parameters: a and BFImax. The parameter a can be determined directly from a graphical analysis of the hydrograph recession, but BFImax is related to the baseflow and total flow relation and can be estimated according to the local geology and the streamflow nature (perennial or ephemeral). Eckhardt (2005) stablished pre-defined values for BFImax ranging from 0.25 to 0.8 . Collischonn and Fan (2013) proposed that the BFImax can be calculated through application of inverse filter or the relation Q90/Q50.

One example of Eckhardt's method application is from Mattiuzi et al. (2016), that used Eckhardt Filter to estimate groundwater recharge rates in the Ibicuí River basin in Rio Grande do Sul Brazil through baseflow separation. The authors adopted the Collischonn and Fan (2013) proposal for the calculation of BFImax index through the relation Q90/Q50. The recharge rates varied from 88 to $378.8 \mathrm{~mm} /$ year. The highest recharge rates were observed in geological units with more permeable soils and higher values of transmissivity and rainfall. The lower rates occurred on crystalline geological units, with low rainfall and clayey soils.

Gonzales et al. (2009) studied the baseflow in a flat land in the Netherlands. Many methods were used for the hydrograph separation, including those based on chemical tracers. The authors verified that Eckhardt's Filter with the BFImax parameter calibra ted through chemical tracer (dissolved silica) presented the best results.

In fractured aquifers, a research performed by the U.S Geological Survey (USGS) by Risser et al. (2005) in Pennsylvania state (USA) showed that the estimation using water table fluctuation should be used with caution due to the aquifer media anisotropy. The baseflow separation presented the most consistent results for the study area.

Moreover, Scalon et al. (2002) found that the choice for the appropriate method usually is a hard task. The most important considerations to be taken include the time/spatial scale. The aim of the study is also an important factor and can determine the scale. The most common studies involve groundwater quantification for management purposes, which requires large time/spatial scales in the analysis; and the evaluation of aquifer vulnerability, which requires detailed spatial scales. In this paper, baseflow separation was used for estimating groundwater recharge on Serra Geral Aquifer System (SASG) in Paraná through digital stream-flow filtering (Eckhardt's Filter). The obtained recharge values can be used as reference for the region for groundwater management and planning.

\section{STUDY AREA DESCRIPTION AND DATA TIME-SERIES}

The study area regards to the outcrop of the Serra Geral Formation in the Paraná state, which is represented by volcanic rocks resulted from Mesozoic magmatism, covering approximately $75 \%$ of the Sedimentary Basin of Paraná. In Brazil, its outcrop extends from the states of Rio Grande do Sul to Minas Gerais, as shown in Figure 1, but it also covers territorial portions of Argentina, Paraguay and Uruguay. The Serra Geral Magmatism consists in a succession of volcanic and the predominant lithotypes presents a basic composition, with interposed acid tufts (rhyolites and riodacites) (LICHT, 2013).

Regarding the hydrogeologic aspects, the outcrop area of SASG in Brazilian territory is approximately $800.000 \mathrm{~km}^{2}(56 \%$ of its occurrence area) and the rest is covered by sediments of the Bauru and Caiuá Groups. In the Paraná state, SASG covers an area of approximately $109.000 \mathrm{~km}^{2}$ and its thickness reaches 1347 meters in Cianorte - PR. It overlay the Guarani Aquifer System, which comprises sandstones of Botucatu and Piramboia Formations. In Paraná it is overlain by Caiuá Aquifer in the northwest region of the state (ATHAYDE and ATHAYDE, 2015). This aquifer has great importance for water supply on Paraná State. According to Sanepar (2015), this aquifer contributes with $57 \%$ of the total groundwater volume supplied by the company. In Paraná, $56 \%$ of the cities are exclusively supplied by groundwater and $22 \%$ by mixed systems (ANA, 2010).

According to Athayde (2012), the limits of the hydrogeological basins coincide with the hydrographic basins. The groundwater flow, in regional scale, occurs from east to west, towards the discharge regions (Paraná and Paranapanema rivers). Locally, the flow occurs towards the main drainages in the state, such as Iguaçu, Ivaí, Piquiri and Tibagi rivers.

The hydrography of the study area is represented by the basins that covers the outcrop area of SASG in Paraná, which are: Iguaçu, Piquiri, Ivaí, Pirapó, Tibagi and Cinzas. The area is limited by Rio Paranapanema in north and Rio Paraná in west.

Figure 2 presents the physical characteristics of the study area. The hydrography map presents the watersheds localization, the main rivers and the gauge stations used. The elevation map was obtained from SRTM (Shuttle Radar Topography Mission) and the model was adapted to the Brazilian reference system by Weber et al. (2004) and as a 90m cell resolution. The declivity map was elaborated from this model and the class intervals are defined according to the Embrapa (1979) classification. The soil type map was obtained from the Paraná Soil Map (scale 1:600,000) by Embrapa (2009). The most common soils are latosols, neosols and nitisols. Regarding the infiltration capacity of these soils, CPRM (2014) classify latosol as very good capacity; neosol as moderate capacity; and nitisol as good capacity. The physical characteristics of each basin are summarized on Table 2.

Streamflow time-series data was obtained from Hidroweb of Brazilian National Water Agency (ANA), except for the Iguaçu River, which naturalized flow data in the Salto Caxias hydroelectric power plant was obtained from National Electrical System Operator (ONS). The gauge stations are listed and described in Table 1. 
Figure 1 - Localization of the study area and Paraná Basin occurrence in Brazil


Table 1 - Fluviometric gauge stations used (ANA 2016)

\begin{tabular}{|c|c|c|c|c|c|c|}
\hline Gauge ID & Name & River & Latitude & Longitude & Time-series & $\begin{array}{c}\text { Drainage } \\
\text { area }\left(\mathrm{km}^{2}\right)\end{array}$ \\
\hline- & UHE S. Caxias & Iguaçu & $-25^{\circ} 32^{\prime} 36$ & $-53^{\circ} 29^{\prime} 33^{\prime \prime}$ & $1999-2014$ & 70800 \\
\hline 64830000 & Balsa Sta Maria & Piquiri & $-24^{\circ} 09^{\prime} 58^{\prime \prime}$ & $-53^{\circ} 44^{\prime} 09^{\prime \prime}$ & $1996-2010$ & 20900 \\
\hline 64693000 & N. P. Taquara & Ivaí & $-23^{\circ} 11^{\prime} 53^{\prime \prime}$ & $-53^{\circ} 18^{\prime} 15^{\prime \prime}$ & $1995-2010$ & 34400 \\
\hline 64550000 & Vila S. Jardim & Pirapó & $-22^{\circ} 51^{\prime} 25^{\prime \prime}$ & $-52^{\circ} 04^{\prime} 41^{\prime \prime}$ & $1999-2008$ & 4490 \\
\hline 64507000 & UHE Jataizinho & Tibagi & $-23^{\circ} 14^{\prime} 29^{\prime \prime}$ & $-50^{\circ} 59^{\prime} 02^{\prime \prime}$ & $2000-2008$ & 21900 \\
\hline 64370000 & UHE C. Andirá & Cinzas & $-23^{\circ} 05^{\prime} 09^{\prime \prime}$ & $-50^{\circ} 17^{\prime} 07^{\prime \prime}$ & $1995-2010$ & 5637 \\
\hline 64390000 & $\begin{array}{l}\text { UHE C. Porto Sta Tere- } \\
\text { sinha }\end{array}$ & Laranjinha & $-23^{\circ} 07^{\prime} 21^{\prime \prime}$ & $-50^{\circ} 27^{\prime} 01^{\prime \prime}$ & $2000-2008$ & 3440 \\
\hline
\end{tabular}

Table 2 - Physical characteristics of each watershed

\begin{tabular}{ccccc}
\hline River & Rainfall (mm/year) & Fractured aquifer area (\%) & $\begin{array}{c}\text { Average slope } \\
\text { (\%) }\end{array}$ & Predominant soil types \\
\hline Iguaçu & 1821,6 & 57.25 & 10.98 & Neosol and latosol \\
Piquiri & 1738,7 & 82.08 & 9.59 & Latosol and neosol \\
Ivaí & 1575,28 & 48.95 & 9.85 & Latosol and neosol \\
Pirapó & 1433,4 & 73.68 & 6.29 & Latosol and nitisol \\
Tibagi & 1508,2 & 27.31 & 9.86 & Latosol and cambisol \\
Cinzas & 1433,4 & 26.37 & 10.24 & Argisol and neosol \\
Laranjinha & 1433,4 & 34.9 & 10.5 & Argisol and neosol \\
\hline
\end{tabular}


Figure 2 - Physical characteristics of the study area: hydrography (a), elevation (b), slope (c) and soil type (d)

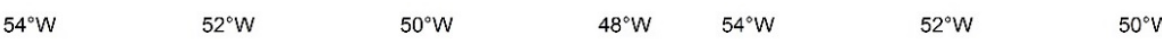
$50^{\circ} \mathrm{W} \quad 48^{\circ} \mathrm{W}$
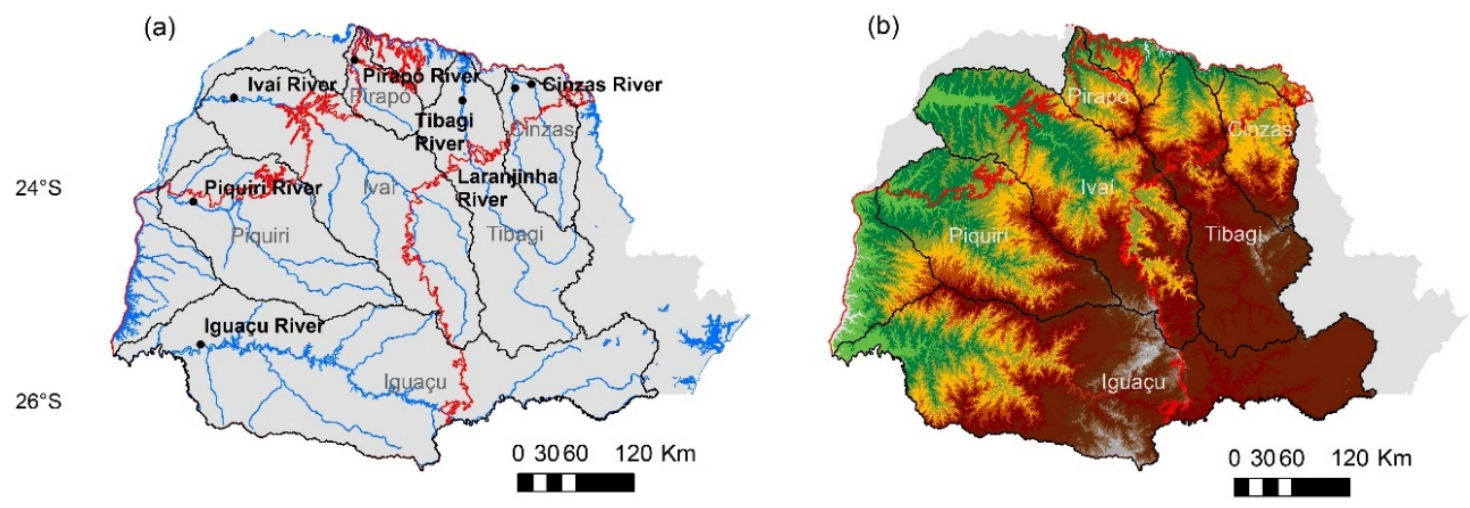

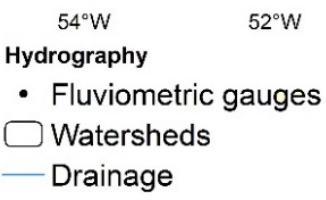

$54^{\circ} \mathrm{W}$ $52^{\circ} \mathrm{W}$ $50^{\circ} \mathrm{W}$

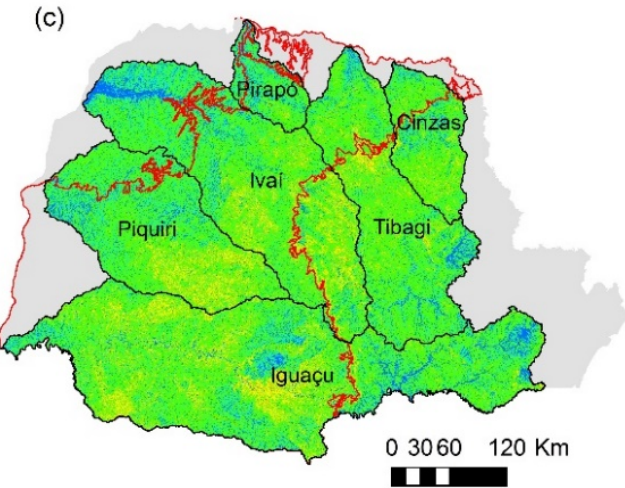

$$
54^{\circ} \mathrm{W}
$$
$52^{\circ} \mathrm{W}$
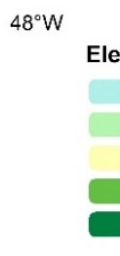

$\begin{array}{lrr}\begin{array}{l}54^{\circ} \mathrm{W} \\ \text { vation (meters) }\end{array} & 52^{\circ} \mathrm{W} & 50^{\circ} \mathrm{W} \\ 85 & 401-500 & 1001-1100 \\ 86-100 & 501-600 & 1101-1200 \\ 801-700 & 1201-1300 \\ 101-200 & 601-800 & 1301-1400 \\ 201-300 \square & 701-800 \\ 301-400 \square & 801-1000 \square \\ 1401-1500 \\ 54^{\circ} \mathrm{W}\end{array}$

$48^{\circ} \mathrm{W}$

(d)

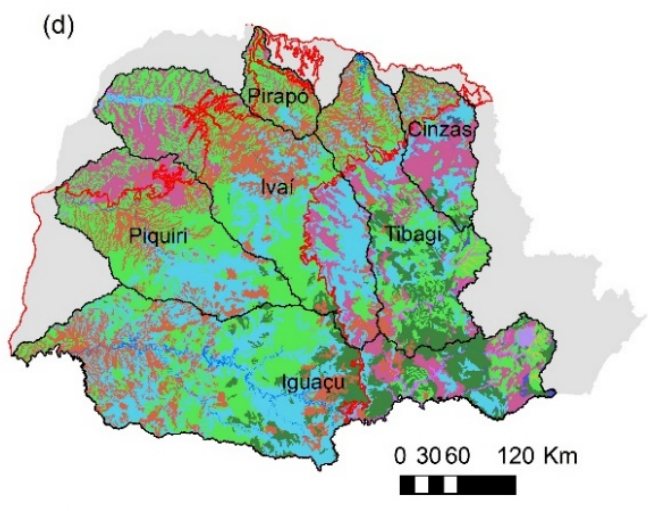

$54^{\circ} \mathrm{W}$

$52^{\circ} \mathrm{W}$

$50^{\circ} \mathrm{W}$

$48^{\circ} \mathrm{W}$

Slope (\%)

Flat (0-3) Strong-wavy (20-45)

Soft-wavy (3-8) Mountainous (45-75)

Wavy (8-20) Strong-mountainous (>75)

Soil type

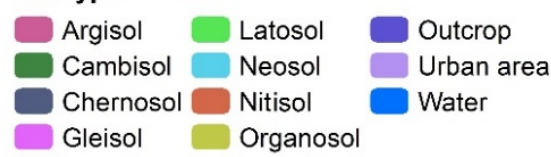

$\stackrel{N}{N}$

\section{MATERIAL AND METHODS}

The annual groundwater recharge estimation in SASG was performed by baseflow separation using a digital recursive filter on streamflow time-series of the rivers presented in Figure 2. The application of digital filters is a suitable method for hydrograph separation and it considers the long-term flow, thus, the river discharge values can be considered as aquifer recharge. The Eckhardt (2005) filter was used and BFImax parameter was calculated according to Collischonn and Fan (2013) methods: Inverse Filter (IF) and Q90/Q50 Ratio (QR); and compared to pondered Eckhardt's pre-defined values (EP). The ponderation was based on the local geology.

In general, digital filters are algorithms that calculate the baseflow through the baseflow separation of a river in two components (Eckhardt 2005), according to Equation 1.

$$
y_{-} i=f \_i+b_{-} i
$$

Where: $y=$ total river flow; $f=$ surface flow; $b=$ baseflow; $k=$ time step. Considering that the baseflow in any time step must be equal or lower than the total river flow, Eckhardt (2005) demonstrated that most digital filters used in specific situations come from a generic model (Equation 2):

$$
b_{i}=A b_{i-1}+B y_{i}
$$

In Eckhardt's digital filter, the $A$ and $B$ parameters are defined by:

$$
\begin{aligned}
& B=\frac{(1-a) B F I_{\max }}{1-a B F I_{\max }} \\
& A=\left(\frac{1-B F I_{\max }}{1-a B I_{\max }}\right) x a
\end{aligned}
$$

Therefore, the equation can be expressed as:

$$
b_{i}=\frac{\left(1-B F I_{\max }\right) a b_{i-1}+(1-a) B F I_{\max } y_{i}}{1-a B F I_{\max }}
$$

where $a$ is a parameter determined by the recession analysis and BFImax is related to the baseflow and total flow ratio. It was 
obtained from the analysis of several hydrograph recessions segments and an average value was calculated for each river.

The definition of BFImax is based on the local geology and streamflow nature (perennial or ephemeral). The values were pre-defined at 0.8 for perennial rivers with porous aquifer; 0.5 for ephemeral rivers with porous aquifer; and 0.25 for perennial rivers with fractured aquifer. These values should be used as a first approximation (ECKHARDT, 2005). According to Collischonn and Fan (2013), the greatest inconvenience presented by Eckhardt Filter consists of the difficulty of estimating BFImax, because this parameter is based on the predominant geological features of the watershed. Therefore, this value is hard to stablish due to heterogeneity of the aquifer types in a basin. Regarding this limitation, the mentioned authors proposed two different ways to estimate BFImax based on inverse filter application and in the Q90/Q50 $\neg$ ratio.

The first proposal (IF), considers that, over long-time periods without rainfall, streamflow is maintained by baseflow and the baseflow in aquifer is linearly proportional to its storage. Therefore, reorganizing the following equation, it is possible to obtain the baseflow in a previous time step (bi-1), which would result in a present value of baseflow, given a value for the constant $a$.

$$
b_{i-1}=\frac{b_{i}}{a} \text {, as long as } b_{i-1}<y_{i-1}
$$

This equation can be transformed into a backward filter which can be applied in the hydrograph in order to obtain a preliminary maximum possible flow value.

$$
\mathrm{b}_{\mathrm{i}}{ }^{\prime}=\frac{\mathrm{b}^{\prime}}{\mathrm{a}}
$$

Considering that the hydrograph generated by b' presents the maximum possible value of baseflow given a recession parameter a, the BFImax estimation can be carried out by dividing the sum of b' by the sum of total flow $y$, according to the following equation:

$$
B F I_{\max }=\frac{\sum_{\mathrm{i}=1}^{\mathrm{N}} \mathrm{b}_{\mathrm{i}}^{\prime}}{\sum_{\mathrm{i}=1}^{\mathrm{N}} \mathrm{y}_{\mathrm{i}}}
$$

The authors applied the proposed methodology to estimate BFImax for daily flow data in fifteen gauge stations in South of Brazil. Results showed that the obtained values were similar to those suggested by Eckhardt (2005), considering the predominant hydrogeology in each basin.

The second proposal (QR) consists of estimating BFImax based on the ratio between flows with permanence of $90 \%$ and $50 \%$. The authors stablished the following relation between BFImax and Q90/Q50:

$$
\mathrm{BFI}_{\max }=0.8344 \frac{\mathrm{Q}_{90}}{\mathrm{Q}_{50}}+0.2146
$$

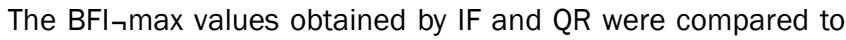
Eckhardt's pre-defined values with a ponderation (EP). Taking into account that all the rivers are perennial, it was considered that the values should range from 0.25 (100\% of the area covered by fractured aquifer) to 0.8 (100\% of area covered by sedimentary aquifer) according to the percentage of aquifer type in the basin (fractured or sedimentary). Intermediary values are observed when at the same watershed there is occurrence of both aquifer types. The different obtained values of BFImax were compared.

Recharge rates in $\mathrm{mm} /$ year were calculated and the obtained values were compared to average rainfall obtained from annual isohyets (time-series from 1977 to 2006) provided by Pinto et al. (2011) and physical parameters presented on topic 2.1 .

\section{RESULTS AND DISCUSSION}

Table 3 presents the values of calculated BFImax for each watershed.

Table 3 - BFImax values calculated for each basin

\begin{tabular}{ccccc}
\hline River & Fractured aquifer area \% & IF method & QR method & EP method \\
\hline Cinzas & $26.37 \%$ & 0.512 & 0.605 & 0.655 \\
Tibagi & $27.31 \%$ & 0.778 & 0.604 & 0.65 \\
Laranjinha & $34.90 \%$ & 0.341 & 0.594 & 0.608 \\
Ivaí & $48.95 \%$ & 0.654 & 0.634 & 0.531 \\
Iguaçu & $57.25 \%$ & 0.676 & 0.555 & 0.485 \\
Pirapó & $73.68 \%$ & 0.749 & 0.73 & 0.395 \\
Piquiri & $82.08 \%$ & 0.711 & 0.585 & 0.349 \\
\hline
\end{tabular}

According to Eckhardt (2005), basins in which fractured aquifers are predominant, BFImax should be around 0.25 and 0.75 for sedimentary. On Piquiri and Pirapó basins, fractured aquifers are predominant, but BFImax $\neg$ calculated through IF and QR presents high values, close to the pre-defined values for sedimentary aquifer. This may be associated to the flow conditions of the SASG, which is a basaltic-rock aquifer. A large amount of opened fractures along with secondary porosity caused by cooling features, such as columnar joints, allow the vertical flow through the basalt, which favors the aquifer recharge (MILLER, 1999). Also, the horizontal groundwater flow in volcanic-rock aquifers is favored by horizontal discontinuity, represented by tops and bottoms of lava flows and interflow zones (SPILLER, 2005). Collischonn and Fan (2013) calculated BFImax values for several gauge stations in Brazilian rivers. Those located on predominant volcanic-rock aquifers presented higher BFImax values than those on crystalline-rock aquifers. Besides, according to the Hydrogeological Map of Brazil (CPRM, 2014b), the water productiv ity in SASG is higher than in others fractured aquifers on Brazilian territory, which can be associated to its higher recharge rates. Furthermore, Dora (2013) found that the Eckhardt's filter 
using pre-defined values underestimated recharge values on basaltic aquifer basins on Rio Grande do Sul state.

Figure 3 presents a graphic representation of linearized BFImax values with respect to the fractured aquifer area percent. It is possible to observe that higher occurrence of SASG in the basin results in a higher difference of IF and QR methods with respect to EP. Also, the BFImax values for IF and QR methods increases when the fractured aquifer area is higher. This suggests that the BFImax values for volcanic rock aquifers are higher than crystalline rock aquifers.

The graphic analysis showed that IF and QR methods presented positive correlation and similar values. These methods have the advantage of not needing pre-defined values, which can be inaccurate due to aquifer geology heterogeneity.

Figure 3 - Linearized BFImax values for each method



The annual recharge rates considering the three methods for calculating BFImax are presented on the Table 4 . The graph in Figure 4 presents a comparison between the recharge values calculated by baseflow separation. For a better understanding of recharge rates, the values were compared to physical characteristics information of each watershed presented on Table 2.
Table 4 presents recharge rates values in $\mathrm{mm}$ /year, obtained by dividing baseflow by the watershed area, and in percent of annual rainfall, obtained by dividing annual recharge by annual rainfall.

Table 4 - Annual recharge rates for each basin

\begin{tabular}{ccccccc}
\hline \multirow{2}{*}{ Rio } & \multicolumn{2}{c}{ Recharge - IF } & \multicolumn{2}{c}{ Recharge - QR } & \multicolumn{2}{c}{ Recharge - EP } \\
\cline { 2 - 7 } & mm/year & \% rainfall & mm/year & \% rainfall & mm/year & \% rainfall \\
\hline Iguaçu & 316.46 & $17.37 \%$ & 319.55 & $17.54 \%$ & 287.76 & $15.80 \%$ \\
Piquiri & 489.18 & $28.14 \%$ & 473.21 & $27.22 \%$ & 307.50 & $17.69 \%$ \\
Ivaí & 375.34 & $23.83 \%$ & 345.50 & $21.93 \%$ & 305.46 & $19.39 \%$ \\
Pirapó & 284.63 & $19.86 \%$ & 280.16 & $19.54 \%$ & 166.44 & $11.61 \%$ \\
Tibagi & 301.25 & $19.97 \%$ & 343.60 & $22.78 \%$ & 363.81 & $24.12 \%$ \\
Cinzas & 194.61 & $13.58 \%$ & 215.95 & $15.07 \%$ & 226.92 & $15.83 \%$ \\
Laranjinha & 156.89 & $10.95 \%$ & 220.60 & $15.39 \%$ & 224.40 & $15.66 \%$ \\
\hline
\end{tabular}

Figure 4 - Comparative graphic of annual recharge rates calculated by each method



The graphic of Figure 4 showed that IF method and QR method presents similar values of recharge. The highest relative difference of QR in relation to IF was observed in the Laranjinha basin and the lowest in the Iguaçu basin. By performing a hypothesis for mean (two-sample t-test), taking as mean the average recharge values by IF and QR method, considering a significance level equal to 0.05 , it was verified that the null hypothesis that the mean values are the same cannot be rejected $(p$-value $=$
0.834). Thus, it can be concluded that the differences observed are at an accepted level, considering the uncertainties involved.

The highest annual recharge rates calculated by baseflow separation refers to Piquiri River basin. These values can be explained by the high rainfall rates, low declivity and high infiltration rates soils. On the other hand, Cinzas River basin (which includes Laranjinha River basin) presented the lowest recharge 
rates. These values are related to low rainfall rates, higher declivity areas the soil type.

Whereas recharge rates in $\mathrm{mm} /$ year is a function of rainfall and physical characteristics in a watershed, recharge values in percent of rainfall is entirely related to physical characteristics only. Therefore, the information in Table 2 can be compared to recharge in percent of rainfall in Table 4. It is not possible to stablish a relationship between recharge and fractured aquifer area percent, which means that in this study area, the aquifer type (fractured or sedimentary) may not be the most important factor in determining the recharge rates in a basin. On the other hand, declivity and soil type appear to influence the obtained results. Higher recharge rates in percent of rainfall is related chiefly to lower declivity values and latosol.
For a better representation of the baseflow separation results, Figures 6 and 7 presents hydrographs for 2007 of the Laranjinha and Pirapó Rivers, which have different flow behavior. In the Laranjinha River hydrograph, the flow undergoes a fast response to rainfall events and presents several flow peaks throughout the year and a low baseflow. The average flow calculated in Laranjinha River for the historical series of 2000-2008 is $61 \mathrm{~m}^{3} / \mathrm{s}$ and the baseflow calculated by Eckhardt's Filter using Inverse Filter is $17 \mathrm{~m}^{3} / \mathrm{s}$. In Pirapó basin, the river flow (57 $\mathrm{m}^{3} / \mathrm{s}$ average) is sustained mostly by the baseflow $\left(41 \mathrm{~m}^{3} / \mathrm{s}\right.$ average).

Figure 5 - Laranjinha River hydrograph in 2007

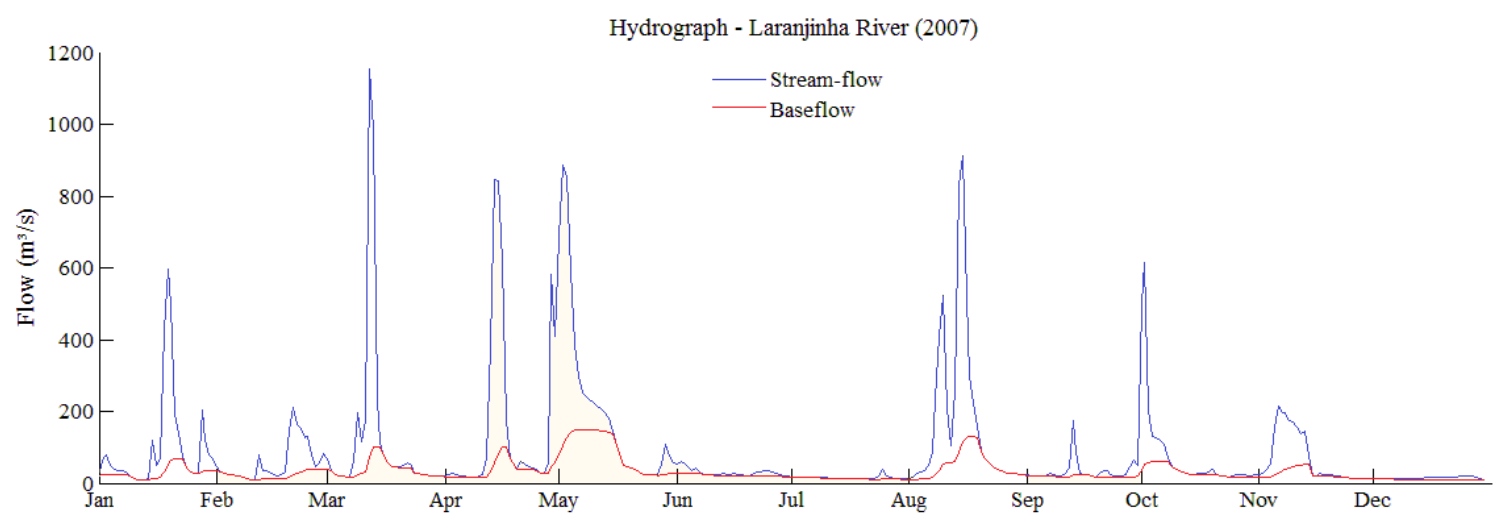

Figure 6 - Pirapó River hydrograph in 2007



The advantage in using baseflow separation is that it needs only one parameter, which is average daily flow. However, it is not possible to perform a spatial distribution of the results if there is not enough sub-watersheds stream-flow data. The existence of several fluviometric gauge stations distributed throughout watersheds is not a reality in Brazil and many other countries. Besides, it is not possible to estimate recharge for periods shorter than a year because the baseflow in each month does not refer to the corresponding recharge on that month, but to previous recharge events, since the baseflow occurs slowly, conditioned by the rock pores and fractures.

Average recharge rates were calculated by each method as an approximation for the region. These values are presented on Table 5 . The three methods presented similar average values, but IF and QR presented slightly higher values than the EP values. The lower value presented by EP method is a result of the underestimation of the pre-defined values for volcanic-rock aquifers. 
Table 5 - Annual average recharge rates in SASG

\begin{tabular}{ccc}
\hline Method & Average recharge (mm/year) & Average recharge (\% rainfall) \\
\hline IF method & 355.59 & $20.81 \%$ \\
QR method & 352.08 & $20.61 \%$ \\
EP method & 293.81 & $17.20 \%$ \\
\hline
\end{tabular}

\section{CONCLUSION}

Baseflow separation approach was used to estimate recharge rates in the SASG and the Eckhardt Filter was applied using three different methods for BFImax calculation: IF, QR and EP. The results suggest that the BFImax for volcanic-rock aquifer is higher than crystalline-rock aquifers.

The recharge values obtained for the study area showed to be influenced by physical parameters (soil type and slope). The highest recharge rates were identified in lower declivity areas and latosol occurrence areas.

The methods IF and QR showed strong correlation. As to the EP method, the differences tend to grow with the increase of fractured aquiver covering, which may indicate that the pre-defined BFImax values for fractured aquifers underestimate recharge for volcanic-rock aquifers, such as the SASG. Therefore, the methods IF and QR are recommended because they do not start from pre-defined values and are based on hydrological response.

Average values of recharge for SASG in Paraná were calculated using IF, QR and EP methods (355.59 mm/year, 352.08 $\mathrm{mm} /$ year and $293.81 \mathrm{~mm} /$ year, respectively). The groundwater recharge evaluation can contribute for a better management of water resources in the Paraná state, considering quantitative aspects. As to the qualitative aspects, the results can be useful in aquifer vulnerability to contamination evaluation.

\section{ACKNOWLEDGEMENTS}

This work was conducted during a research project, financed by CNPq, project number 446685/2014-3, “Mapeamento multifinalitário no Sistema Aquífero Serra Geral, Estado do Paraná: áreas potenciais à captação para consumo humano, e vulnerabilidade natural à contaminação do aquífero" coordinated by Prof. Dr. Gustavo Barbosa Athayde (Instituto de Pesquisas Hidráulicas - UFRGS).

\section{REFERENCES}

ANA, Agência Nacional de Águas. Atlas de abastecimento urbano de água, $2010 \quad$ Disponível em: <http://atlas.ana.gov.br/Atlas/forms/Home.aspx>. Acesso em: 5 nov. 2015.

ANA, Agência Nacional de Águas. Hidroweb. Disponível em: < http://hidroweb.ana.gov.br/>. Acesso em: 5 nov. 2015.

ALLER, L., et al. DRASTIC: a standardized system for evaluating groundwater pollution potential using hydrogeologic settings. U.S Environmental Protection Agengy, 622 p., Oklahoma, 1987.

ATHAYDE, G. B. Compartimentação hidroestrutural do sistema aquifero Serra Geral (SASG) no Estado do Paraná, Brasil. Tese (Doutorado)UFPR, Curitiba, 2013.

ATHAYDE, G. B; ATHAYDE, C. V. M. Hidrogeologia do Sistema Aquífero
Serra Geral no Estado do Paraná. Revista brasileira de águas subterrâneas, v. 29, n 3, 2015, p 315 - 333.

CIVITA, M. V.; DE MAIO, M. Valutazione e cartografia automatica della vulnerabilità degli acquiferi all' inquinamento con il sistema parametrico: SINTACS R5, a new parametric system for the assessment and automaticmap ping of groundwater vulnerability to contamination. Bologna: Pitagora, 2000. 240 p.

COLISCHONN, W.; FAN, F. M. Defining Parameters for Eckhardt's Digital Baseflow Filter. Hydrological Process, n. 27, p. 2614 - 2622, 2013.

CPRM, Serviço Geológico do Brasil. Mapa hidrogeológico do Brasil ao milionésimo. Instruções técnicas, 2014a.

CPRM, Serviço Geológico do Brasil. Mapa hidrogeológico do Brasil ao milionésimo. Pernambuco, 2014b - Escala 1:5.000.000.

DORA, A. S. Quantificação de reservas renováveis de água subterrânea em bacias hidrográficas a partir de séries históricas de vazão: Uma ferramenta para a gestão de bacias. Trabalho de conclusão de curso (Graduação)-Universidade Federal do Rio Grande do Sul, Porto Alegre, 2013.

ECKHARDT, K. A Comparison of base flow indices, which were calculated with seven different baseflow methods. Journal of Hydrology, n. 352, p. 168-173, 2008.

ECKHARDT, K. How to construct recursive digital filters for baseflow separation. Hydrological Process, n. 19, p. 507-515, 2005.

EMBRAPA. Mapa de solos do Paraná. Paraná, 2009 - Escala 1:600.000.

EMBRAPA, Empresa Brasileira de Pesquisa Agropecuária. Serviço Nacional de Levantamento e Conservação de Solos (Rio de Janeiro, RJ). Súmula da $10^{a}$ reunião técnica de levantamento de solos. Rio de Janeiro, $83 \mathrm{p}, 1979$.

FRANCÉS, A.; PARALTA, E.; FERNANDES, J.; \& RIBEIRO, L. Development and application in the alentejo region of a method to assess the vulnerability of groundwater to difuse agriculture pollution: the susceptibility index. lisboa, geosystem center ist, third international conference on future groundwater Resources at Risk, 2001.

GONZALES, A. L.; NONNER, J.; HEIJKERS, J.; UHLENBROOK, S. Comparison of different base flow separation methods in a lowland catchment. Hydrology and Earth System Sciences, v. 13, p. 2055 - 2068, 2009.

HEALY, R.W.; COOK, P.G. Using groundwater levels to estimate recharge. Hydrogeology Journal, v. 10, n. 1., p. 91-109, Berlin, 2002.

LEE, K. K.; RISLEY, J. C. Estimates of ground-water recharge, base flow, and stream reach gains and losses in the willamete river basin, Oregon. U.S. Geological Survey, Portland, Oregon, 2002.

LICHT, O. A. B. O grupo serra geral no Estado do Paraná. Serviço Geológico do Paraná - Mineropar, Curitiba, 2013.

MATTIUZI, C. D. P.; KIRCHHEIM, R.; COLLISCHONN, W.; FAN, F. M. Estimativa de recarga subterrânea a partir da separação do escoamento de base na bacia hidrográfica do Rio Ibicuí. Águas Subterrâneas, v. 29 n. 3 , p. 285 - 300, jan. 2016.

MILLER, J. A. Ground Water Atlas of the United States. U. S. Geological Survey, Introduction and National Summary. Available in: < https://water.usgs.gov/ogw/aquiferbasics/volcan.html >. Acess in jun. 15, 2017. 
PINTO, E. J. A., et al. Estimativa de Recarga Natural do Aquífero Livre de Uma Sub-bacia da Bacia Representativa de Juatuba (MG) Aplicando o Método de Variação dos Níveis D'água. In: CONGRESSO BRASILEIRO DE ÁGUAS SUBTERRÂNEAS, 16., 2010. Anais... São Luiz - MA, 2010.

RISSER, D.W.; GBUREK, W.J.; FOLMAR, G.J. Comparison of methods for estimating ground-water recharge and base flow at a small watershed underlain by fractured bedrock in the eastern United States. U.S. Geological Survey Scientific Investigations Report, 31 p, 2005.

SANEPAR. Companhia Paranaense de Saneamento. March 31, 2015 news. Available <http://site.sanepar.com.br/noticias/aquiferos-fornecem-21-da-agua-tratada-consumida-pelos-clientes>. Acess in November 6, 2015.

SCALON, B. R.; HEALY, R. W.; COOK, P. G. Choosing Appropriate Techniques for Quantifying Groundwater Recharge. Hydrogeology Journal, $\mathrm{n}$ 10, p. 18 - 39, 2002.

SIMMERS, I. Estimation of natural groundwater recharge. NATO ASI Series C 222. Reidel, Dordrecht, 510 p., 1998.
SILVA, A. J. P.; LOPES, R. C.; VASCONCELOS, A. M.; BAHIA, R. B. C. Bacias Sedimentares Paleozóicas e Meso-Cenozóicas Interiores. In: Geologia, Tectônica e Recursos Minerais do Brasil. CPRM, Brasília, 2003.

SPILLER, L. E. Estruturas Armazenadoras e Qualidade das Águas Subterrâneas do Aquífero Serra Geral em São Paulo. In.: XIV Encontro Nacional de Perfuradores de Poços e II Simpósio de Hidrogeologia do Sudeste. São Paulo, 2005

STEWART, M.; CIMINO, J.; ROSS, M. Calibration of Base Flow Separation Methods with Streamflow Conductivity. Ground Water, v. 45 n. 1, p. 17-27, 2007.

WEBER, E.; HASENACK, H.; FERREIRA, C. J. S. Adaptação do modelo digital de elevação do SRTM para o sistema de referência oficial brasileiro e recorte por unidade da federação. Porto Alegre, UFRGS Centro de Ecologia. 